\title{
The Status of the Foreign Arbitral Award According to the Albanian Legislation Provisions in Light of the New York Convention: Formal and Substantial Issues
}

\author{
Artan Spahiu $^{1} \&$ Arber Gjeta ${ }^{1}$ \\ ${ }^{1}$ Department of Law, "A.Xhuvani" University, Elbasan, Albania \\ Correspondence: Artan Spahiu, Department of Law, Faculty of Economy, "A.Xhuvani" University, Elbasan, \\ Albania. Tel: 355-69407-0009. E-mail: artan_spahiu@yahoo.com
}

Received: September 16, 2013 Accepted: September 27, 2013 Online Published: October 16, 2013

doi:10.5539/ilr.v2n1p145

URL: http://dx.doi.org/10.5539/ilr.v2n1p145

\begin{abstract}
The role played by foreign investments for the integration and economic development of Albanian commerce in European area and beyond is undisputed. These investments, as well as other commercial relationships between national and foreign businesses, need an attractive legal environment, especially in regard of legal certainty. There is the need, essentially, for guaranties in regard to the rules that assure a fair treatment and the eventual dispute resolution by reliable legal instruments.

It is a priority therefore to foresee modern alternative dispute resolution mechanisms and their effective use. Arbitration, especially the international arbitration is considered the most important legal instrument. According to these developments the Albanian legislation should modernize some aspects of the international arbitration institute, which is widely used in international commercial relations, in example recognition and enforcement of foreign arbitral awards.

In this article is our intention to discuss, in a comparative light, some important issues in Albanian legal framework, compared to the New York Convention provisions, concerning the arbitral award status and obstacles for its recognition and enforcement in the Republic of Albania.
\end{abstract}

Keywords: arbitral award, New York Convention, recognition, Albanian legislation

\section{Introduction: Legal Instruments that Enable the Recognition and Enforcement of Foreign Arbitral Awards in Albania}

In the Albanian legal framework the recognition and enforcement of foreign arbitral awards is regulated by two legal instruments: provisions of the New York Convention (Note 1) and the Code of Civil Procedure.

Convention on the Recognition and Enforcement of Foreign Arbitral Awards (New York Convention, 1958), in the thoughts of Albert Jan van den Berg, considered as 'father of the Convention, is identified as the most successful treaty in the field of international private law (Note 2). Actually it is applied by 146 contracting States, becaming part of their national jurisdiction. The influence of the Convention upon the international commercial arbitration is undisputed because it has constituted two fundamental pillars of the international legal framework. Firstly, the Convention guarated the enforcement of any foreign arbitral award in the conractiong States (Note 3). Secondly, it has essentially modified the relationship between arbitration agreement and the national court jurisdiction, because the contractiong States agreed that a valid arbitration agreement to be a sufficent legal ground for the national courts to decline their jurisdiction favoring the settlement of commercial disputes by arbitration (Note 4). Empirical studies proves that one of the main reasons why the parties choose international arbitration to settle their disputes is the possibility to enforce the arbitration awards according to the uniform pprovisions set out in the New York Convention (Moses, 2008, p. 3). The Albanian parliament has approved the accession of the Republic of Albania in the New York Convention (Note 5) and consequently, based on Constitutional sources of law ranking (Note 6), the provisions of this Convention have become part of national legal system, prevailing over national laws. So the provisions of the New York Convention prevail, in case of conflict, over the provisions of the Code of Civil Procedure, in terms of legal regulations applying for recognition and enforcement of foreign arbitral awards. 
The second instrument that governs the recognition of foreign arbitral awards is the National Law. Albanian Code of Civil Procedure includes some important provisions regarding to this issue, which treat recognition of foreign arbitral awards as a special judgment (Note 7). The judicial decisions of the courts of foreign states and final awards of a foreign arbitration are recognized and enforced in the Republic of Albania according to the same rules (art.399 C.C.P.).

It is our aim, through this paper, to assess the real effect of these two moments in the Albanian legal system and if their observance in practice responds to the emerging importance of the international arbitration for settling commercial disputes.

\section{The Application of the New York Convention as an Integral Part of Albanian Legal System}

The Albanian Republic has adopted the New York Convention by the Law n.8688 of 09.11.2000 "Për aderimin e Republikës së Shqipërisë në "Konventën për njohjen dhe ekzekutimin e vendimeve të huaja të arbitrazhit" (Note 8). Due to this accession the Albanian Republic undertakes to accomplish the international obligations which derive from the Convention:

- the recognition and enforcement of foreign arbitral award (article I).

- the recognition of the agreement for submitting to international arbitration all or any dispute that might arise between parties (article II/1).

- the exclusion of the national court's jurisdiction (article II/3).

- the correct application of the effective enforcement of the foreign arbitral awards (article III).

In order to implement these obligations set by the Convention it rises the need, firstly, to determine the status of the arbitral award, if we are in presence of an domestic or a foreign arbitral award. The New York Convention recognizes as "foreign award" those which (a) are made in the territory of a State other than the State where the recognition and enforcement are sought and (b) those not considered as domestic awards in the State when the recognition and enforcement are sought (Note 9). In relation to the first criteria it is evident that an arbitral award made outside Albanian territory should be considered as a "foreign arbitral award" and it should pass through the procedure of recognition and enforcement in Albania. Regarding the application of the second criteria of the Convention, for the arbitral awards which are taken in Albanian territory, some issues arise in determining their status of "domestic" or "foreign" and their inclusion in the scope of the Convention.

There are different helpful criteria foreseen in the internal legislation in order to define if an arbitral award should be considered as "domestic" in a State where the recognition and enforcement are sought. As regards the distinction between domestic and international (or foreign) arbitration, the Albanian legislation distinguishes these two institutes by the provision of article 400 of the Code of Civil Procedure. This article, through subjective criteria, determines that the provisions on internal arbitration (art.400-438 of CCP) shall apply to an arbitration procedure only if the two following conditions are met: (a) when participants in the process (the parties) are domiciled or residing in the Republic of Albania and (b) when the seat of the arbitration procedure is located in the Albanian territory. Furthermore, it is important to mention the article 427 of the Albanian Code of Civil Procedure which states that "Arbitral tribunal shall apply the Albanian legislation". A combined reading of these two provisions led us to the interpretation that the Albanian legal framework on arbitration (articles 400 to 438 C.C.P.) shall apply as procedural law for any arbitration if the two conditions are both met: (a) the parties are domiciled or resident in Albania and (b) the parties have choose the Republic of Albania as the seat of arbitral proceedings.

In the light of the determination of the status of an international arbitral award a question rises in regard to the internal legislation: the above interpretation should mean that the arbitral tribunal seated in Albania, if the two conditions are met, shall apply the Albanian legislation as a procedural law even when the parties have differently opted by contractual provision? In other words, should the arbitral tribunal consider the parties preferences regarding the procedural law or should apply as mandatory the Albanian CCP provisions?

Problems arises only apparently in the light of the liberal approach that the doctrine (Born, 2000, IIed, p. 450; Moses, 2008, p. 63-65) and the Convention provisions have toward the international arbitration institute when the parties are free to select not only the legislation governing on the merit of dispute (substantive law), but even the procedural rules which should govern the arbitral process. The freedom of the parties in order to freely determine the procedural rules of the arbitration process is foreseen in several national legislations (Note 10).

The New York Convention offers a definitive answer to this dilemma which arises in the internal legislative provisions. According to the Convention it is considered a legal ground to refuse the recognition of the award 
when "[t]he composition of the arbitral authority or the arbitral procedure was not in accordance with the agreement of the parties, or, failing such agreement, was not in accordance with the law of the country where arbitration took place" (Note 11). The Convention itself recognizes and gives priority to the regulation of procedural rules of arbitration according to the agreement between parties, which are free to select a foreign law to govern the arbitration. Thereof, such agreement shall prevail on the internal procedural law of the State in which the arbitration shall have place. Identic provision can be observed in the UNCITRAL Model Law on International Commercial Arbitration of 1985 (as amended in 2006) which in its article 19(1) determines that: "[s]ubject to the provisions of this Law, the parties are free to agree on the procedure to be followed by the tribunal in conducting the proceedings".

Returning to our topic, we can affirm that the Albanian procedural law should be used during the arbitral proceedings when the challengers are Albanian and the arbitration have seat in Albania, except when the parties have agreed to opt for a different procedural law. In this sense the provision of article 427 C.C.P ("Arbitral tribunal shall apply the Albanian legislation") may be considered as an additional criterion for identifying the conditions that should be met in order to consider the arbitral procedure as a domestic arbitration (local). According to these considerations, regarding the criteria imposed by article 400 and 427 C.C.P., we can assert that the definition of a procedure and the consequent award as "domestic" is assured only if these three conditions are met:

(a) the parties are domiciled or residing in the Republic of Albania;

(b) the parties have chosen the Republic of Albania as the seat of arbitral proceedings;

(c) the court of arbitration applies the Albanian legislation.

Therefore, arbitration seated and concerning parties which reside or are domiciled in Albania, cannot and should not be qualified as "domestic arbitration" when the challengers have preferred a different procedural law than the Albanian. In such situation we are in presence of an "international arbitration" and the subsequent decision should be defined as "non domestic" or "foreign" arbitral award according to the New York Convention as in regard of recognition and enforcement procedure. In line with this statement we stress the importance of the provisions of the Model Law, which define an arbitral procedure as international if, beside other factors, the parties "have expressly agreed that the subject matter of the arbitration agreement relates to more than one country" (Note 12).

Regarding the scope of application of the New York Convention and the interpretation of "non-domestic award" one of the leading cases in international panorama is the case Sigval Bergesen vs. Joseph Muller Corp (Note 13). In this case, the Court of Appeal of the United States concludes that the sole seat of procedure and the procedural law are not sufficient criteria for defining an arbitral award as internal/domestic. These two criteria are not relevant, according to the Court, if the litigation or the connection between parties has a considerable relationship with another State, different to the United States. This relevant case helps us to understand the standard set up by leading jurisprudence concerning the "nationality" of the arbitral award, if it should be considered domestic or foreign.

Returning to our topic it is important to emphasize that this standard is not followed if we apply the Albanian legislation. The Albanian C.C.P. foresees the same juridical treatment, considering as domestic that arbitration which lays on conflicts between parties, whom relationship presents foreign or international elements (mixed nationality, performing of contract outside Albania, etc.), if the criteria of residence or domicile and the seat of arbitration is Albania. In other words, the Albanian legislation considers as a domestic arbitral award those which are made by an arbitral tribunal in Albania between two foreign subjects, which are temporary domiciled in Albania, even if the conflict derives from a commercial relationship that has no connection with Albania. Furthermore, the strict interpretation of the article 427 C.C.P. can lead to a paradox situation when an Albanian Court, in this hypothetic situation, can recognize as invalid the agreement between the foreign parties to choose a procedural law for the process of arbitration which is different from the Albanian legislation.

The described panorama of the Albanian legislation regarding the concept of "nationality" of the process of arbitration and its award, which determines its status as domestic or foreign will be more clear if to the mentioned articles of C.C.P. should follow an additional provision on international arbitration, as it is disposed in article 439 of C.C.P. (Note 14), but it is not yet approved an appropriate legislation on international arbitration. 


\section{The Discipline of the Recognition of Foreign Arbitral Awards According to the Code of Civil Procedure, in Comparison with the Convention Provisions. Some Problematic Issues.}

The second legal instruments which discipline the recognition of foreign arbitral award are inside the Code of Civil Procedure provisions (Note15). Foreign State courts decisions or arbitral awards can produce their effects in the Republic of Albania (Note 16) but their enforcement is subject to preventive recognition by the Albanian judicial authority. Once the recognition is achieved the foreign arbitral award has equal effects and power as a domestic decision because it becames an Albanian court decision (Brati, 2008, p. 413).

The arbitral award recognized by the Court of Appeal receives legal authority of an executive title and can be forcefully executed after releasing an executive order. It is better illustrated by the judicial practice. In example, in the decision on the plea made by McKinsey \& Comany Inc.Croatia (Note 17) the Court of Appeal has stated that the arbitral award is an executive title and from this title derives rights for the claimant and one of these is the legitimation to request the issue of an executive order.

Moved by the above considerations, in our opinion the provisions of the C.C.P. practically assure the effective recognition and the enforcement of a foreign arbitral award in Albania like every other final judicial decision. As we can notice, in the case AEDP vs. Republic of Albania (Note 18), Decision no.54 on 29.05.2007, the Court of Appeal has ruled that: "... Civil Division of the Court of Appeal of Tirana, in accordance with articles 393 and following has decided: ... the recognition and the enforcement of the arbitral award of the International Court of Arbitration (ICC) no.13962/FM of 20.10.2006". Again, in the case "BE-HA-SE" vs. General Department of Roads, Ministry of Public Affairs, Transport and Telecomunications of Albania (Note 19) the Court has assessed the so-called "legal grounds for refusal" of the recognition and enforcement. In accordance with the dispositions of article 394 C.C.P. and article 5 of New York Convention, the Court concluded that it does not subsist any obstacle to justify the refusal of the enforcement of the foreign award and has granted the recognition of the award.

\subsection{The First Issue: Final or Internal Arbitral Award}

The recognition and enforcement of a foreign arbitral award is possible, due to the Code of Civil Procedure provisions, only if the claimant filed, among other documents that follows the request for recognition, a certification that the decision is "final" (Note 20), excluding from the recognition interim awards issued by an arbitral tribunal. In our opinion this provision of the Code of Civil Procedure results problematic, at least for its linguistic formulation. The refusal of recognition of interim decisions, disposed in the article 396 C.C.P., is referred to the decisions issued by a foreign judicial court. Anyway, in the light of article 399 C.C.P. (Note 21), as the other provisions of this Chapter (Note 22), this provision shall similarly apply to the recognition and enforcement of a foreign interim arbitral award, which mean the refusal of the recognition of the awards issued during the proceedings.

The Albanian case law has supported this narrow interpretation of the provision, at least in regard to the foreign state judicial decisions. In example, in the case Sky Petroleum INC vs. Republic of Albania, the Court of Appeal of Tirana analyses the plea presented by Sky Petroleum INC for the recognition of the Decision of the Court of Texas (USA) for an "Interim order of security" (Note 23). The Court of Appeal has concluded that the interim decision of the Court of Texas (USA), which disposes on measures for issuing an order of security on the object of the claim, is not to be considered as final according to the principles of the Albanian legislation. Therefore, the request of Sky Petroleum INC on the recognition of this decision has not a legal ground and has to be refused based on the article 394(d) and 396 of C.C.P., which state that: "the decision of a foreign State court shall not be enforced in the Republic of Albania when ... it had been given the 'final' status contrary to its legislation" and "the request for obtaining legal enforcement for the decision of a foreign state court shall have in attach ... the certification, from the court which has issued the decision, that it is to be considered as final".

Such interpretation, despite it is apparently based on law, seems to be incorrect in the case of the recognition and enforcement of an interim award. Even that the spirit of the New York Convention refers to the execution of the final arbitral awards, which does not mean that we should exclude apriori from the effects of the Convention the interim or partial awards. According to relevant doctrine in these cases it will be the substantial content and the effects of the interim award the factors that should be considered as important in order to determine the status as final of the arbitral award (Moses, 2008, p. 182). This assumption and the subsequent possibility for granting recognition effects to the interim award, in accordance with the dispositions of New York Convention, is confirmed even by judicial practice (Note 24).

Moving by the above considerations, in our opinion it will be likeable to re-write or to re-interpret the rigid interpretation of the C.C.P. on foreign state court decisions (as foreseen by article 394(d) and 396 C.C.P.). There 
is a need to mitigate the consideration of this criterion ("final" decision) as absolute for granting the recognition and to open the possibility even for interim award. The nature of "final" should be assessed in a case by case basis from the competent court, taking into account the substantial content of the arbitral award (even of the interim arbitral award) and its effects upon the parties.

\subsection{The Second Issue: The Applicable Law for the Recognition}

Some problems rises by the application of Article 399 of the Code of Civil Procedure (Note 25), which does not clearly explain whether the provisions of the Chapter entitled "On the recognition of foreign State decisions" (Note 26) will also be applied to foreign arbitral awards respecting strictly the provisions of this Chapter, or only to the extent that the content of these provisions does not fall in contradiction with the features of an arbitral process (which means application according to the mutatis mutandis principle).

The equal treatment that the Code reserves to the recognition of the foreign state judicial decisions and arbitral awards, which despite a formal similarity maintain their substantial peculiarities, have to be considered exceeded. The C.C.P. provisions should be applicable to both situations as far as their application does not affect the ratio of the arbitral process. In Albanian case law it is confirmed by the jurisprudence which has stated on the effects of the C.C.P. provisions over the procedure of the foreign arbitral award recognition. In the case "BE-HA-SE" vs. General Department of Roads, Ministry of Public Affairs, Transport and Telecomunications of Albania (Note 27), the Civil College of the Court of Appeal of Tirana disposes an interpretation on the legal framework that the Courts should apply for the recognition of the foreign arbitral award. In its reasoning the Court finds that the sequent provisions of the C.C.P. should be used:

-article 399 C.C.P. which disposes on the application of the provisions of Chapter IX of C.C.P. "On the recognition of foreign State decisions";

-article 393 C.C.P. of Chapter IX disposes that: "the decisions of foreign state courts are recognized and enforced in the Republic of Albania in accordance with the conditions foreseen in this Code or in other special laws. When on this matter there is a specific agreement [Treaty] between Republic of Albania and the foreign State the disposition of the agreement [Treaty] shall apply";

-the Republic of Albania has ratified by law no.8688 of 09.11.2000 the Convention "On the Recognition and Enforcement of Foreign Arbitral Awards", which, in application of the article 122(2) of the Albanian Constitution, prevail on the domestic legislation.

Consequently, the Court of Appeal has concluded that, in the application of the hierarchy of the sources of law and the lex specialis derogat generalis principles, for the recognition of the international (foreign) arbitral award the Court shall apply the dispositions of the New York Convention and the provisions of the Code of Civil Procedure only when the latest are non in conflict with the Convention.

The only provisions which can prevail on the New York Convention and the C.C.P. provisions are the bilateral agreements between Republic of Albania and a foreign State, whose object is the mutual recognition and enforcement of their respective arbitral awards (Note 28). This is supported even by the provisions of the New York Convention which, through a "most favorable" clause, allows presenting the recognition claim based on the domestic law of the court or on the bilateral or multilateral treaties (which may foresee "most favorable" conditions) which are in force in the State where the recognition is sought (Note 29).

Therefore, we notice a clear hierarchy of the normative acts which regulate the procedure of recognition of a foreign arbitral award, and in practice it is as follows:

i) specific bilateral agreements on the mutual recognition of the arbitral awards between Republic of Albania and a foreign State;

ii) New York Convention provisions;

iii) Code of Civil Procedure of the Republic of Albania.

3.3 The Third Issue: The Excess of "Obstacles" of the Code of Civil Procedure for the Recognition and Enforcement of a Foreign Arbitral Award

Recognition of a foreign arbitral award represents the judicial procedure for verifying the legal requirements, through which the arbitral award is been given the legal power to be enforceable on the Albanian territory (Brati, 2008, p. 414). In fact the Code of Civil Procedure does not expressly provide the conditions for the recognition of a foreign arbitral award, but on the contrary it provides the conditions that are considered as "barriers" for recognition, known as the "grounds" for refusal of enforcement. It is understood that in any other circumstance 
not included in the framework of these legal restrictions, a foreign arbitral award can and should be given executive powers.

Specifically, a foreign arbitral award shall not have effects (that means it is not recognized and enforced) in the Republic of Albania, under the following conditions:

i) When, under provisions in force in the Republic of Albania, the dispute concerned by the decision (award) might not be in the competence of the court of arbitration of the state that has issued the decision (award) (Note 30)

ii) When the lawsuit and the summons have not been notified to the defendant in absence on the default and orderly time, to give him the opportunity to be defended. (Note 31)(the principle of due and equal process to the parties).

iii) When, between those same parties for the same subject and the same reason, a different decision has been given by the Albanian court. (Note 32)(the res judicata principle).

iv) When the foreign arbitral award has become final in contradiction with the law under which the award was made. (Note 33)

v) When the foreign arbitral award is not in accordance with basic principles of the Albanian legislation. (Note 34) (the public policy principle).

vi) When the Albanian court is examining a lawsuit that is presented before the foreign arbitral award has become final. (Note 35). Such an obstacle is assessed by the Court of Appeal of Tirana in the Decision no.122 dated 14.12.2010. In the case regarding the recognition in the Republic of Albania of the Award, issued by the International Court of Arbitration of ICC no.14869/A VH/JEM/GZ Rohde Nielsen A/S vs. Ministry of Transport and Telecomunications of Republic of Albania, dated 19.10.2009, the Court of Appeal finds that: "There does not exist any pending process between these parties in an Albanian Court, and the claimant has proved by a certification, issued by the Court of Tirana no.6115/1 dated 15.11.2010, which confirm that there is no pending civil lawsuit concerning Rohde Nielsen $A / S^{\prime}$.

This legal ground seems redundant in the group of grounds which may justify the refusal to enforce a foreign award, arguing as follow:

-First of all, such a provision laid down on the article 394(4) of CCP to prevent the recognition of foreign arbitral awards exceeds the conditions known as the grounds for refusing the recognition and enforcement of a foreign arbitral award, provided by the New York Convention (Note 36).

-Secondly, such a final obstacle to the recognition of the award, provided by the CCP, falls in contradiction with the obligations imposed by the ratification of the New York Convention, specifically with the obligation to exclude the jurisdiction of a national court when it is seized of an action in a matter, in respect of which the parties have made an arbitral agreement (Note 37). In implementing this obligation, the Albanian court if it's examining a lawsuit (action), should declare the lack of jurisdiction when there is an arbitral agreement between the parties. The submission of the arbitration agreement by an interested party should be enough for the court to declare the lack of jurisdiction. In these circumstances, the fact that the Albanian court is examining a lawsuit in a matter, in respect of which the parties have made an arbitral agreement, means that this court is acting in the lack of jurisdiction and this fact should not prevent the recognition and enforcement of a foreign arbitral award, as currently provided from the article 394(4) of CCP.

-Thirdly, the provision of article 394(4) reopens the issue of verification of competence or incompetence of the arbitration forum. As already mentioned, the Code of Civil Procedure makes a specific prediction about the competence of the arbitral forum, when it provides as an "obstacle" to recognition of foreign arbitral award the fact that the dispute concerned by the award might not be in the competence of the court of arbitration that has issued the award (CCP, art.394(1)) (Note 38). The confirmation of the validity of the arbitration forum competence implies indirect proof of incompetence of the Albanian court to examine a lawsuit over the dispute. It seems that we are dealing with the same ground for refusal of enforcement, as provided from the article 394(1), but repeated in another form in the provision of article 394(4).

-Fourthly, the refusal of enforcement of an arbitral award due to the submission of a lawsuit in an Albanian court, before the moment of time that the award has become final, as provided by the article.394(4), may be used intentionally as an artificial barrier to the enforcement of an award from the party against whom it is invoked. This party may file a lawsuit in an Albanian court deliberately to refuse later the enforcement of the foreign arbitral award, issued over the dispute, in Albania. In example, in the case Rohde Nielsen A/S, the Court of 
Appeal would have refused to recognize the arbitral award if the defendant had presented a lawsuit in front of an Albanian Court against Rohde Nielsen A/S. This would be contrary to the spirit of the New York Convention, whose aim is to facilitate the conditions for recognition and enforcement of foreign arbitral awards. Normally, the arbitration agreements between parties in a commercial relationship preclude the possibility for submitting a claim in front of a different Court that is not the agreed seat of the proceedings.

\subsection{The Fourth Issue: The Burden of Proof}

Provisions of the CCP do not predict who has the burden of proving to the Court of Appeal that one or more legal grounds of refusal, mentioned above, are met. In fact, article 397 of CCP stipulates that "[t]he Court of Appeal examines whether the present award applied for enforcement does not contain provisions that conflict with article 394". In general interpretation of this provision, the Court of Appeal may examine the existence of the grounds of refusal on its own motion (ex officio), without request of the interested party.

Whereas the New York Convention is very clear at this point, when stipulates the obligation of the party against whom the award is invoked: first to make a request for refusal of the arbitral award applied for enforcement and second to submit evidences to the competent authority to prove the grounds of refusal (Note 39). There are only two grounds on which a court may refuse enforcement on its own motion, which are exhaustively listed in the second paragraph of Article $\mathrm{V}$, concerning the non-arbitrability of the dispute and the violation of public policy under the law of the forum (Note 40).

3.5 The Fifth Issue: The Code of Civil Procedure does not Provide for Submission of the Arbitration Agreement as a Condition for Recognition and Enforcement of Foreign Arbitral Awards

According to the CCP provisions, the formal request for recognition and enforcement of a foreign arbitral award should be followed by some documents, in order to be considered regular. Specifically the following documents are required to be submitted: (a) copy of the foreign arbitral award, which is subject to the application for recognition; (b) certificate of the arbitral forum, which issued the award to certify that this award has become final; (c) power of attorney, if the application is filed by a representative of the interested party (Note 41). These documents are required to be duly translated and authenticated.

As above, the provisions of the Code of Civil Procedure do not require as a condition the submission of "arbitration agreement" by the party applying for recognition and enforcement of the award. Such a prediction does not comply with the provisions of the New York Convention (Note 42), where the application for enforcement of the award is provided to be accompanied by the "arbitration agreement", otherwise the formal request for enforcement is not considered regular.

\section{Final Remarks and Recommendations}

\subsection{Concluding Reflections}

The recognition and enforcement of foreign arbitral award should be submitted through a lawsuit in front of an Albanian Court of Appeal, which is obliged to issue a declarative decision that recognize the legal power and juridical effects of the award in the Albanian territory. The consequent executive power of the award is granted in two phases. The first phase is the request for recognition of the award and it is concluded by issuing a court decision of recognition. The second phase is a different judicial procedure, proceeded from the same Court of Appeal, which concerns the issuing of an executive order based on the recognized award (Note 43). This executive order is the conclusion of the procedural phase of the recognition and enforcement and it constitutes a direct executive title for the claimant which has legal power inside the Republic of Albania.

The Albanian Code of Civil Procedure, compared to the dispositions of the New York Convention, in our opinion, shows some problematic issues. Regardless the ratification of the New York Convention by the Republic of Albania, the recognition and enforcement of international (foreign) arbitral awards in Albania is being carried out through a non-contemporary national legal framework:

a. A group of provisions of the Albanian Code of Civil Procedure governs the recognition and enforcement of foreign arbitral awards in reference to the recognition of the foreign State courts decisions. The national law does not provide a direct disposition for the recognition and enforcement of foreign arbitral awards. The complete conformity of the grounds for refusal of enforcement of these two different categories of decisions (judicial decisions and arbitral awards) cannot be considered the best choice.

b. The provisions of the CCP are not fully in accordance with the provisions of the New York Convention, regarding the recognition and enforcement of foreign arbitral awards. These discrepancies, which may create obstacles to judicial procedures for enforcing foreign arbitral awards in practice, are mentioned briefly as follow: 
-The New York Convention clearly provides to the interested party the right to refuse the enforcement of a foreign arbitral award, but also the burden of proving the grounds for refusal. Provisions of the CCP does not make such a prediction and consequently the Court of Appeals on its own initiative (without request of the interested party), controls whether foreign arbitral award contains elements that constitute the legal grounds for refusing its enforcement.

-The provisions of the CCP do not require the submission of "arbitration agreement" from the party concerned, as a validity condition of the request for enforcement, in contrast to the New York Convention which foresee as mandatory the submittion of the "arbitration agreement" in order that the request for recognition and enforcement to be acceptable by the competent authority.

-The article 394 of CCP provides a legal ground for refusal of enforcement of a foreign arbitral award, which not only exceeds those provided by the New York Convention but also may become an obstacle in practice to implement the spirit of the Convention.

\subsection{Recommendations}

Albanian legislation needs to be updated, aiming the approach to the contemporary spirit and principles of international legal framework. In this regard, the legal regulation of recognition and enforcement of foreign arbitral awards by the provisions of a special law would be a solution. A hypothetical law, for example "On arbitration" or "On commercial arbitration", could be the proper act to consolidate the legal framework, regulating both the internal and international procedures of arbitration (Darling \& Caushi, 2008, p. 81). In this way the obligation that derives from the article 439 of Albanian Code of Civil Procedure will be fulfilled (Note 44).

A good option would have been to make part of domestic law the UNCITRAL Model Law provisions, which on one side do not conflict with the provisions of the New York Convention and in turn improve the recognition procedures of international arbitration awards (Note 45). A similar pattern which can be applied to reference is the Arbitration Act - English Law of Arbitration - which in its third section regulates the recognition and enforcement of foreign arbitral awards (Note 46).

Another possible version of a contemporary regulation of the recognition and enforcement of foreign arbitral awards is to amend the provisions of the Albanian Code of Civil Procedure. For analogy, our domestic law might be referred to the provisions of the Italian Code of Civil Procedure, which directly govern the international arbitration (Note 47) and the recognition of foreign arbitral awards in Italy (Note 48). A likeable change in the C.C.P. is the redefinition of the applicable criteria for determining the arbitration and its consequent effects as a domestic or foreign (international). An appropriate criterion is the applicable procedural law in the arbitral proceedings (the law selected by the parties or the law chosen by the tribunal). In our opinion it is needed a specific disposition that would offer a clear determination of the domestic and foreign arbitration like, in example, the definition of the arbitration agreement in the UK Arbitration Act, from which derives a clear definition of the status of the procedure and the consequent arbitral award (Note 49).

Furthermore, we propose a redefinition of the "final" nature of the award as an indispensable condition for the recognition and enforcement in Albania. The "final" nature of the award should be assessed in a case by case basis, by the Court seized by the claimant. The Court should consider the substantial content of the award (including interim awards) as well as the consequences that it produces for the interested parties.

In the case of Albania, the adoption of a special law on arbitration, or the amendment of the provisions of CCP, is becoming a necessity in the present conditions when the Albanian economy is increasingly oriented towards new borders, putting on the spotlight the expansion of trade relations, particularly international ones. To meet the needs of an open market, its actors (businesses and individuals) naturally will be looking for more effective legal instruments of conflict resolution. At this point, special attention should be paid by the domestic law to those legal instruments that serve to the recognition and enforcement of foreign arbitral awards.

\section{References}

Arbitration Act 1996 (UK).

Bergesen vs. Joseph Muller Corp. (710 F.2d 928, 2d Cir.1983).

Born, G. B. (2001). International Commercial Arbitration - Commentary and Materials (2nd ed.). The Hague: Kluwer Law International.

Brati, A. (2008). Proçedura Civile. Tirane: Dudaj.

Code of Civil Procedure of Albania. 
Constitution of the Republic of Albania.

Convention on the Recognition and Enforcement of Foreign Arbitral Awards (1958) - New York Convention.

Darling, S., \& Caushi, A. (2008). The International Comparative Legal Guide "On the international arbitration 2008", A practical insight to cross-border International Arbitration work; Global Legal Group Ltd. London, with the contribution of "Kalo \& Associates, Attorneys at Law".

Decision of Court of Appeal of Tirana no.106 dated 08.11.2007 La Petrolifera Italo-Rumena S.p.A. and La Petrolifera Italo-Albanese Sh.A. vs. Republic of Albania.

Decision of Court of Appeal of Tirana no.122 dated 14.12.2010 Rohde Nielsen A/S vs. Ministry of Transport and Telecomunications of Republic of Albania.

Decision of Court of Appeal of Tirana, no. 32/1010 dated 01.03.2012 Sky Petroleum INC vs. Republic of Albania.

Decision of the Court of Appeal n. 34 of 31.03.2009 "BE-HA-SE" vs. General Department of Roads, Ministry of Public Affairs, Transport and Telecomunications of Albania.

Decision of the Court of Appeal n. 54 of 29.05.2009, n. reg. 22 of 22.02.2007 AEDP vs. Republic of Albania.

Decision of the Court of Appeal of Tirana n.55 of act, n. 43 decision of 10.05.2007 McKinsey \& Comany Inc.Croatia vs. Republic of Albania.

Italian Civil Procedure Code.

Law no.7760 dated 14.10.1993. Rep. Alb. Off. Journal no.12, p.787.

Law no.8688 dated 09.11.2000 "On accession of the Republic of Albania in the "Convention on the Recognition and Enforcement of Foreign Arbitral Awards"

Moses, M. L. (2008). The Principles and Practice of International Commercial Arbitration. New York: Cambridge University Press. http://dx.doi.org/10.1017/CBO9780511819216

UNCITRAL Model Law on International Commercial Arbitration, 21 June 1985 as amended on 7 July 2006; United Nations documents A/40/17, annex I and A/61/17, annex I.

UNCITRALs' questionnaire dated 16.01.2008 (published by UNCITRAL on 31.08.2010).

Yasuda Fire \& Marine Ins. Co. of Europe v. Continental Cas. Co., 37 F.3d 345 (7th Cir. 1994).

\section{Notes}

Note 1. Convention on the Recognition and Enforcement of Foreign Arbitral Awards (1958)- drafted and submitted for signature on 10 June 1958 by the UN Cnference "On the International Commercial Arbitration", upon the Resolution 604 (XXI) of ECOSOC of 3 May 1956.

Note 2. http://untreaty.un.org/cod/avl/ha/crefaa/crefaa.html. (last access on 29 September 2013)

Note 3. New York Convention, Art.III: "Each Contracting State shall recognize arbitral awards as binding and enforce them in accordance with the rules of procedure of the territory where the award is relied upon, under the conditions laid down in the following articles. There shall not be imposed substantially more onerous conditions or higher fees or charges on the recognition or enforcement of arbitral awards to which this Convention applies than are imposed on the recognition or enforcement of domestic arhitral awards".

Note 4. New York Convention, Art.II(3): "The court of a Contracting State, when seized of an action in a matter in respect of which the parties have made an agreement within the meaning of this article, shall, at the request of one of the parties, refer the parties to arbitration, unless it finds that the said agreement is null and void, inoperative or incapable of being performed".

Note 5. By Law no.8688 dated 09.11.2000 "On accession of the Republic of Albania in the "Convention on the Recognition and Enforcement of Foreign Arbitral Awards".

Note 6. The Constitution of the Republic of Albania, art.116 (1); art.122(2).

Note 7. Art. 393-399, Part II, Title III, Chapter IX "Recognition of judgments of foreign states" Code of Civil Procedure of Albania.

Note 8. Law n. 8688 of 09.11.2000, Official Journal n. 38, p. 1836.

Note 9. Article 1 (1) of New York Convention. 
Note 10. In example the article 816 Italian Civil Procedure Code (Arbitral Proceedings) states that: "The parties can foresee in the arbitral agreement or in a separate document signed previously of starting of the arbitration proceedings, the rules of procedure and the language that the arbitrators shall use. In the absence of such rules the arbitrators have the authority to establish their own rules and to select the language of the proceedings as they see more appropriate".

Note 11. Article V(1)(d) of New York Convention.

Note 12. UNCITRAL Model Law on International Commercial Arbitration, 21 June 1985 as amended on 7 July 2006, article 1(3)(c); United Nations documents A/40/17, annex I and A/61/17, annex I.

Note 13. Bergesen vs. Joseph Muller Corp. (710 F. $2^{\mathrm{d}}$ 928, $2^{\mathrm{d}}$ Cir.1983).

Note 14. The Chapter VI of Title IV of the C.C.P., entitled "International Arbitration", contains only one provision (article 439), which states that "the international arbitration is regulated by a special law". Two other provisions of this chapter (article 440 and 441), on the definition of the procedure of international arbitration and on the applicable law, have been repealed.

Note 15. Article 393-399 of C.C.P. "The recognition of foreign State's awards".

Note 16. The answer of the Republic of Albania to the UNCITRALs' questionnaire dated 16.01.2008 (published by UNCITRAL on 31.08.2010).

Note 17. Decision of the Court of Appeal of Tirana no.55 of act, no. 43 decision dated 10.05.2007 on the recognition and enforcement of the award in accordance with article 510 C.C.P.: the plaintiff McKinsey \& Comany Inc.Croatia request in front of the Court the recognition and enforcement of the arbitral award LCIA no. 5720 on 04.06 .2006 . The award, which was issued by a monocratic arbitral tribunal, has confirmed the plaintiff assertions against the Union of Chambers of Commerce and Industry of Albania and Albanian Agency for the Developement of Foreign Investments, whom have to respond solidarly toward McKinsey \& Comany Inc.Croatia for the amounts. Therefore, the Court of Appeal issued an executive order.

Note 18. Decision of the Court of Appeal n. 54 of 29.05.2009, n. reg. 22 of 22.02 .2007 on the recognition and enforcement in the Republic of Albania of the arbitral award of the International Court of Arbitration (ICC) $n$. 13962/FM of 20.10 .2006

Note 19. Case n. 90006-00372-30-2009, as registered in the Court of Appeal of Tirana in 19.02.2009 concluded by the Decision no. 34 dated 31.03.2009 on the recognition in the Republic of Albania of the arbitral award of the International Court of Arbitration (ICC) n. 12016/ACS/FM on 02.04.2008.

Note 20. Article 396 of CPC.

Note 21. Article 399 (rubricated "Arbitral court award") C.C.P. disposes that: "[t]he provisions of this Chapter also apply on the recognition of a final award of a foreign State arbitration".

Note 22. Chapter 9 of III Title "On the recognition of the awards issued in foreign States (Statal courts)", C.C.P.

Note 23. The claimant Sky Petroleum INC is a corporate established in USA which had presented a claim in Texas (USA) in order to assure an order of security on the claim object before the presentation of a claim to the International Arbitration of the ICC, Zurich. The Court of Texas has accepted the claim with an internal decision and has granted the order of security. Decision of Court of Appeal of Tirana, no. 32/1010 dated 01.03.2012

Note 24. See Yasuda Fire \& Marine Ins. Co. of Europe v. Continental Cas. Co., 37 F.3d 345 (7th Cir. 1994) ("interim order of security" found to be a final award under the U.S. Federal Arbitration Act).

Note 25. Article 399 (rubricated "Arbitral court award") C.C.P. disposes that: "[t] he provisions of this Chapter also apply on the recognition of a final award of a foreign State arbitration".

Note 26. Article 393-399, Part II, Title III, Chapter IX C.C.P.

Note 27. Decision of the Court of Appeal of Tirana no.34 dated 31.03.2009 "The recognition in the Republic of Albania of the Award issued by the International Court of Arbitration of ICC no.12016/ACS/FM of 02.04.2008.

Note 28. Albania has ratified several agreements, especially with confinant States. It worth to mention the "Convention between the Republic of Albania and Republic of Greece for legal assistance in civil and penal cases", signed in Athens on 17.05.1993, ratified by Law no.7760 dated 14.10.1993. Rep. Alb. Off. Journal no.12, p.787.

Note 29. Article 7 (1), New York Convention. 
Note 30. Article 394, par.1 Code of Civil Procedure of Albania. In example, in the case La Petrolifera Italo-Rumena S.p.A. and La Petrolifera Italo-Albanese Sh.A. vs. Republic of Albania (Decision of Court of Appeal of Tirana no.106 dated 08.11.2007), the preliminary condition of competence of the court of arbitration is met and for this reason the Court has stated, in the process for the recognition of the Award, issued by the International Court of Arbitration of ICC no.14420/FM, dated 25.07.2007, that "the award issued by the International Court of Arbitration was its competence ... the competence of the forum is based on article 17 of the Concession Agreement dated 24.05.2004".

Note 31. Article 394, par.2, C.C.P.

Note 32. Article 394, par.3, C.C.P.

Note 33. Article 394, par.5, C.C.P.

Note 34. Article 394, par.6, C.C.P.

Note 35. Article 394, par.4, C.C.P.

Note 36. Article 5 New York Convention.

Note 37. Article 2, par. 3 New York Convention states that: "The court of a Contracting State, when seized of an action in a matter in respect of which the parties have made an agreement within the meaning of this article at the request of one of the parties, refer the parties to arbitration unless it finds that the said agreement is null and void, inoperative or incapable of being performed".

Note 38. Article 394, par. 1 C.C.P.

Note 39. Article V(1) New York Convention disposes: "Recognition and enforcement of the award may be refused, at the request of the party against whom it is invoked, only if that party furnishes to the competent authority where the recognition and enforcement is sought, proof that:...".

Note 40. Article V(2) New York Convention: "Recognition and enforcement of an arbitral award may also be refused if the competent authority in the country where recognition and enforcement is sought finds that: ..."

Note 41. Article 396 C.C.P.

Note 42. Article IV(1)(b) New York Convention.

Note 43. Article 510-511, C.C.P.

Note 44 . Article 439 C.C.P. states that: "the international arbitration is regulated by a special law"

Note 45. It suffice to mention the provision of the UNCITRAL Model Law for clarifying the form of arbitration agreement - Article 7, option I and II of the UNCITRAL Model Law.

Note 46. Articles 100-104 UK Arbitration Act 1996

Note 47. Articles 832-838, Chapter VI (International Arbitration) Italian Code of Civil Procedure

Note. 48. Articles 839-840, Chapter VII (On foreign arbitral award) Italian Code of Civil Procedure

Note 49. Article 85(2) Arbitration Act 1996 (UK) states that: "For this purpose a "domestic arbitration agreement" means an arbitration agreement to which none of the parties is (a)an individual who is a national of, or habitually resident in, a state other than the United Kingdom, or (b) a body corporate which is incorporated in, or whose central control and management is exercised in, a state other than the United Kingdom, and under which the seat of the arbitration (if the seat has been designated or determined) is in the United Kingdom".

\section{Copyrights}

Copyright for this article is retained by the author(s), with first publication rights granted to the journal.

This is an open-access article distributed under the terms and conditions of the Creative Commons Attribution license (http://creativecommons.org/licenses/by/3.0/). 